Marquette University

e-Publications@Marquette

Psychology Faculty Research and Publications

Psychology, Department of

4-1-2007

\title{
Clinical Psychologists' Perceptions of Persons with Mental Illness
}

Lynn M. Servais

Marquette University

Stephen M. Saunders

Marquette University, stephen.saunders@marquette.edu

Accepted version. Professional Psychology: Research and Practice, Vol. 38, No. 2 (April 2007):

214-219. DOI. (C) 2007 American Psychological Association. Used with permission. 
Marquette University

e-Publications@Marquette

\section{Psychology Faculty Research and Publications/College of Arts and Sciences}

This paper is NOT THE PUBLISHED VERSION; but the author's final, peer-reviewed manuscript. The published version may be accessed by following the link in th citation below.

Professional Psychology: Research and Practice, Vol. 38, No. 2 (April 2007): 214-219. DOI. This article is (C) American Psychological Association and permission has been granted for this version to appear in $\underline{\mathrm{e}}-$ Publications@Marquette. American Psychological Association does not grant permission for this article to be further copied/distributed or hosted elsewhere without the express permission from American Psychological Association.

\section{Clinical Psychologists' Perceptions of Persons with Mental Illness}

\section{Lynn M. Servais}

Marquette University;

Stephen M. Saunders

Marquette University

Biographical Information for Authors: Lynn M. Servais obtained her PhD in clinical psychology from Marquette University. She is now the Team Leader for the Alcohol and Drug Residential Treatment program at the Veterans Affairs Medical Center, Milwaukee, Wisconsin. Her research interests include addictive disorders, mental health stigma, and the treatment of comorbid conditions.

Stephen M. Saunders obtained his PhD in clinical psychology from Northwestern University. He is Associate Professor and Director of Clinical Training at the Department of Psychology at Marquette University. His research interests include the stigma associated with mental illness and its treatment, the treatment-seeking process, the development of the therapeutic alliance, and the effect of spiritual issues on psychotherapy. 


\section{Acknowledgement:}

Public attitudes toward persons with mental illness may have improved over the years (Bhugra, 1989; Skinner, Berry, Griffith, \& Byers, 1995), but research indicates that members of the public continue to fear persons with mental illness, blame them for their illness, and underestimate their chances of recovery (Corrigan et al., 2000; Levey \& Howells, 1994). These attitudes contribute to the self-stigma and shame experienced by persons with mental illness, decreasing the likelihood that they will seek mental health care (Corrigan, 2004). Clinical psychologists play an important role in correcting public misperceptions by promoting informed attitudes of acceptance and understanding. To do this, clinical psychologists must be aware of their own attitudes and behavior.

The attitudes of clinical psychologists toward persons with mental illness are highly complex and influenced by a wide range of factors, including professional training and personal biases. Both can create negative evaluations that affect subsequent professional behavior. Some negative evaluations are justified (i.e., those based on realistic clinical appraisal), whereas others are not (i.e., those arising from biased perceptions).

One of the primary duties of the clinical psychologist is to provide diagnostic evaluations. These evaluations tend to be negative in tone because the focus is on problematic behavior. For instance, persons with mental illness may exhibit ineffective life skills, they may act irrationally, or they may demonstrate behaviors suggestive of imminent danger to self or others. Although these observations lead to negative evaluations, they nonetheless represent diagnostic characteristics of clinical importance. Such evaluations provide important information about treatment, such as the need to initiate or increase medication or to evaluate for suicidal intent.

However, evaluations made by professionals can also be influenced by interpersonal factors such as likeability, similarity, attraction (Cavior \& Glogower, 1973; Sharf \& Bishop, 1979; Wills, 1978), and "disidentification" (Cumming \& Cumming, 1957; Nunnally, 1961). Disidentification involves the process of characterizing persons with mental illness as easily recognizable and different from "normal" individuals while characterizing oneself as normal and not susceptible to mental illness (Cumming \& Cumming, 1957; Mahatane \& Johnston, 1989). The creation of categories involving such "ingroups" and "outgroups" serves to enhance people's own self-esteem (Hogg \& Abrams, 1988; Tajfel \& Turner, 1986; Turner, Oakes, Haslam, \& McGarty, 1994). Disidentification also allows the belief holder to diminish the threat that mental illness poses to the self-concept and worldview (Lerner, 1980). That is, people who view themselves as similar to those who have a mental illness experience distress because it makes them aware of their own vulnerability to mental illness. Instead, it may be preferable to believe that they are not at the mercy of fate and that mental illness happens only to others who somehow deserve it or who bring it on themselves (Lerner \& Simmons, 1966).

Disidentification is an important concept for psychologists because of its association with prejudicial attitudes. Miles (1981) found that recognizability, dangerousness, and unpredictability were the three characteristics that the public most commonly attributed to persons with mental illness. Levey and Howells (1995) found prejudicial attitudes among the public, psychology undergraduates, and nursing students who all expressed the belief that people with schizophrenia were very different from themselves. Mahatane and Johnston (1989) reported that medical students endorsed unrealistically 
optimistic ideas about their risk of becoming mentally ill. Moreover, the greater the level of optimism expressed by the medical students, the more negative were their attitudes toward persons with mental illness.

As for the mental health profession, prior research suggests that disidentification is operative in the attitudes that some clinicians have toward individuals with substance abuse problems and other forms of mental illness (Potamianos, Winter, Duffy, Gorman, \& Peters, 1985; Ramon, 1978). Disidentification may be present in the tendency of some mental health professionals to place individuals with mental illness into a single category and then view everyone in this category as possessing the same negative qualities and personal characteristics (Atwood, 1982). An example of this is the perception that all alcoholics are in denial. Disidentification also occurs when one feature of an individual is used to define the totality of the individual's existence, such as when mental health professionals refer to clients as their psychological disorder (e.g., "borderlines" and "schizophrenics").

Although clinical psychologists play a major role in the provision of mental health services (Bureau of Labor Statistics, 2004-2005), their attitudes toward persons with mental illness have not been evaluated to the same extent as the attitudes of psychiatrists and social workers. Some studies suggest that clinical psychologists compare favorably to other health professionals, tending to be more positive in their attitudes (Calicchia, 1981b; Roskin, Carsen, Rabiner, \& Marell, 1988) and more optimistic in regard to treatment outcome (Jorm, Korten, Jacomb, Christensen, \& Henderson, 1999; Jorm, Korten, Jacomb, Rodgers, \& Pollitt, 1997).

However, there is also evidence of negative attitudes held by clinical psychologists. For example, studies have found that psychologists were less willing to interact socially with or to accept as a therapy client a person with AIDS than a person with leukemia (Crawford, Humfleet, Ribordy, Ho, \& Vickers, 1991; St. Lawrence, Kelly, Owen, Hogan, \& Wilson, 1990). Kahle and White (1991) found "moralistic attitudes" among psychologists who expressed discomfort with being around individuals with substance abuse problems. Additionally, some clinical psychologists may be reluctant to work with persons with serious and persistent mental illness (Gallagher, Gernez, \& Baker, 1991; Mirabi, Weinman, Magnetti, \& Keppler, 1985).

Psychologists adopt a self-critical approach to their profession, constantly striving to improve the quality of services. The goal of the present study was to obtain a better understanding of how clinical psychologists perceive individuals with mental illness and to determine to what extent clinical psychologists engage in disidentification.

\section{The Survey}

One thousand clinical psychologists were randomly selected from the 1997 Directory of the American Psychological Association (American Psychological Association, 1997), which provides professional information (major field of practice and specialty areas). They were mailed a cover letter, demographic questionnaire, a professional characteristics questionnaire, and an attitude measure. Ninety surveys (9\%) were returned by the post office as undeliverable. The 306 useable surveys returned represent a $34 \%$ response rate. Participants ranged in age from 25 to $74(M=46.4$ years, $S D=7.51)$. Fewer men $(45 \%)$ than women responded. The vast majority (95\%) of the respondents were of Caucasian descent, with only 16 from ethnic minority groups. The average number of years since participants completed 
graduate training was 14.5 years $(S D=7.15)$, and the average number of years of clinical experience was $16.5(S D=7.60)$.

The cover letter explicitly stated that responses would be anonymous and confidential. In addition to demographic information, respondents were asked to indicate what percentage of their workweek was spent in various employment settings. Two thirds (66\%) of the respondents worked in private or group practice for at least half of their workweek, and $42 \%$ were employed exclusively in private practice. Respondents were employed in a variety of other settings at least half of the time, including $12 \%$ in university settings; $10 \%$ in outpatient or inpatient settings; $5 \%$ in community mental health clinics; $3 \%$ in schools; and $8 \%$ in corrections, law enforcement, corporations, private organizations, and government agencies. Participants spent the largest proportion (58\%) of their workweek providing therapy. Other duties included research (4\%), teaching (6\%), consultation (6\%), and supervision (5\%). Respondents who had contact with clients (93\%) estimated that they were much more likely to see mildly (39\%) and moderately (44\%) disturbed clients than severely (17\%) disturbed clients.

To reduce the likelihood of socially desirable responding, we evaluated the attitudes of respondents by using a semantic differential scale method (Osgood, Suci, \& Tannenbaum, 1957). This method measures the semantic meaning or connotation of stimulus words or "targets." The targets are rated by using a series of scales anchored by descriptive word opposites (i.e., adjective pairs representing a continuum, ranging from positive to negative).

Respondents rated five targets on six semantic differential scales. The targets consisted of a selfreferencing target ("yourself"), a nonclinical target ("a member of the public"), and three clinical targets ("a person with moderate depression," "a person with borderline features," and "a person with schizophrenia"). The six semantic differential scales used to rate the targets were selected on the basis of their established ability to discriminate between positive and negative attitudes held by mental health professionals (i.e., Calicchia, 1981a, 1981b; Ramon, 1978; Zolik \& Boyd, 1972). The scales were effective-ineffective, understandable-incomprehensible, safe-dangerous, worthyunworthy, desirable to be with-undesirable to be with, and similar to me-dissimilar to me (note that the target "yourself" was not rated on the scale pair similar to me-dissimilar to me). Respondents rated the targets on each of the adjective pairs by using a 7-point scale, with 1 indicating the most positive end of the scale (e.g., desirable to be with), 4 indicating the neutral point (neither positive nor negative), and 7 indicating the most negative end of the scale (e.g., undesirable to be with).

\section{Findings}

Average ratings of the five targets on each of the six adjective pairs are shown in Table 1. One-way within-subjects analyses of variance (ANOVAs) indicated that target ratings differed for each adjective pair (Fs ranged from 40.95 to 808.86, all $p s<.001$ ). Subsequent paired-sample $t$ tests were conducted to determine which targets were rated as significantly different from others (statistical significance was set at the .005 alpha level to adjust for multiple tests). 
Table 1

Target Ratings for Adjective Pairs

\begin{tabular}{|c|c|c|c|c|c|c|c|c|c|c|c|c|c|c|c|c|c|c|}
\hline \multirow[b]{2}{*}{ Target } & \multicolumn{3}{|c|}{$\begin{array}{l}\text { Effective- } \\
\text { ineffective }\end{array}$} & \multicolumn{3}{|c|}{$\begin{array}{l}\text { Understandable- } \\
\text { incomprehensible }\end{array}$} & \multicolumn{3}{|c|}{$\begin{array}{c}\text { Safe- } \\
\text { dangerous }\end{array}$} & \multicolumn{3}{|c|}{$\begin{array}{l}\text { Worthy- } \\
\text { unworthy }\end{array}$} & \multicolumn{3}{|c|}{$\begin{array}{c}\text { Desirable- } \\
\text { undesirable }\end{array}$} & \multicolumn{3}{|c|}{$\begin{array}{c}\text { Similar- } \\
\text { dissimilar }\end{array}$} \\
\hline & $M$ & $S D$ & $d$ & $M$ & $S D$ & $d$ & $M$ & $S D$ & $d$ & $M$ & $S D$ & $d$ & $M$ & $S D$ & $d$ & $M$ & $S D$ & $d$ \\
\hline Yourself & $1.68_{\mathrm{a}}$ & 0.77 & & $1.74 \mathrm{a}$ & 0.72 & & $1.29_{\mathrm{a}}$ & 0.57 & & $1.37 \mathrm{a}$ & 0.61 & & $1.89_{\mathrm{a}}$ & 0.89 & & $1.00_{\mathrm{a}}$ & 1.00 & \\
\hline A member of the public & 3.36 & 0.98 & 1.50 & $2.87_{\mathrm{b}}^{\mathrm{a}}$ & 1.22 & 0.88 & $3.15_{\mathrm{b}}$ & 1.16 & 1.51 & $2.19 \mathrm{~b}$ & 1.39 & 0.61 & $3.13_{\mathrm{b}}$ & 1.14 & 0.99 & $3.31_{\mathrm{b}}$ & 1.27 & 1.82 \\
\hline A person with moderate depression & $3.84_{\mathrm{e}}$ & 1.39 & 1.45 & $1.53_{\mathrm{c}}$ & 0.83 & -0.20 & $2.90_{c}$ & 1.40 & 1.13 & $1.66_{\mathrm{e}}$ & 1.08 & 0.28 & $3.78_{c}$ & 1.35 & 1.29 & $3.93 \mathrm{c}$ & 1.62 & 1.80 \\
\hline A person with borderline features & $4.83_{\mathrm{d}}$ & 1.43 & 2.11 & $2.99 \mathrm{~b}$ & 1.54 & 0.78 & $4.38_{\mathrm{d}}$ & 1.30 & 2.30 & $1.92_{\mathrm{d}}$ & 1.29 & 0.44 & $4.98_{\mathrm{d}}$ & 1.31 & 2.01 & $5.41_{\mathrm{d}}$ & 1.33 & 3.32 \\
\hline A person with schizophrenia & 5.29 e & 1.51 & 2.30 & $3.68_{d}$ & 1.75 & 1.05 & $3.91_{\mathrm{e}}$ & 1.40 & 1.82 & $1.71_{c}$ & 1.12 & 0.31 & $4.69_{e}$ & 1.38 & 1.68 & 5.69 e & 1.38 & 3.40 \\
\hline
\end{tabular}

Note. Higher mean scores indicate less positive ratings. Means in the same column that do not share subscripts differ at $p<.005$ in the paired-sample $t$ test comparison. The $d$ statistic was calculated as $d=M_{\mathrm{C} 1}-M_{\mathrm{C} 2} / S_{\mathrm{p}}\left(M_{\mathrm{C} 1}=\right.$ mean of Condition $1, M_{\mathrm{C} 2}=$ mean of Condition 2 , and $S_{\mathrm{p}}$ is the pooled standard deviation of the difference scores). Higher $d$ values indicate that the respondent rated greater incompatibility between self and target.

\section{Table 1. Target Ratings for Adjective Pairs}

\begin{tabular}{|c|c|c|c|c|c|c|c|c|c|c|c|c|c|c|c|c|c|c|}
\hline & $\begin{array}{l}\text { Effectiv } \\
e- \\
\text { ineffect } \\
\text { ive }\end{array}$ & & & $\begin{array}{l}\text { Understanda } \\
\text { ble- } \\
\text { incomprehen } \\
\text { sible }\end{array}$ & & & $\begin{array}{l}\text { Safe- } \\
\text { danger } \\
\text { ous }\end{array}$ & & & $\begin{array}{l}\text { Worth } \\
y- \\
\text { unwort } \\
\text { hy }\end{array}$ & & & $\begin{array}{l}\text { Desirabl } \\
e^{-} \\
\text {undesira } \\
\text { ble }\end{array}$ & & & $\begin{array}{l}\text { Similar } \\
- \\
\text { dissimi } \\
\text { lar }\end{array}$ & & \\
\hline Target & $M$ & $S D$ & $d$ & M & $S D$ & $d$ & $M$ & $S D$ & $d$ & $M$ & $S D$ & $d$ & $M$ & $S D$ & $d$ & M & $S D$ & $d$ \\
\hline Yourself & $1.68 \mathrm{a}$ & $\begin{array}{l}0.7 \\
7\end{array}$ & & $1.74 a$ & $\begin{array}{l}0.7 \\
2\end{array}$ & & $1.29 a$ & $\begin{array}{l}0.5 \\
7\end{array}$ & & $1.37 a$ & $\begin{array}{l}0.6 \\
1\end{array}$ & & $1.89 a$ & $\begin{array}{l}0.8 \\
9\end{array}$ & & $1.00 a$ & $\begin{array}{l}1.0 \\
0\end{array}$ & \\
\hline $\begin{array}{l}\text { A member } \\
\text { of the } \\
\text { public }\end{array}$ & $3.36 \mathrm{~b}$ & $\begin{array}{l}0.9 \\
8\end{array}$ & $\begin{array}{l}1.5 \\
0\end{array}$ & $2.87 \mathrm{~b}$ & $\begin{array}{l}1.2 \\
2\end{array}$ & $\begin{array}{l}0.8 \\
8\end{array}$ & $3.15 b$ & $\begin{array}{l}1.1 \\
6\end{array}$ & $\begin{array}{l}1.5 \\
1\end{array}$ & $2.19 b$ & $\begin{array}{l}1.3 \\
9\end{array}$ & $\begin{array}{l}0.6 \\
1\end{array}$ & $3.13 b$ & $\begin{array}{l}1.1 \\
4\end{array}$ & $\begin{array}{l}0.9 \\
9\end{array}$ & $3.31 \mathrm{~b}$ & $\begin{array}{l}1.2 \\
7\end{array}$ & $\begin{array}{l}1.8 \\
2\end{array}$ \\
\hline $\begin{array}{l}\text { A person } \\
\text { with } \\
\text { moderate } \\
\text { depressio } \\
\mathrm{n}\end{array}$ & $3.84 \mathrm{c}$ & $\begin{array}{l}1.3 \\
9\end{array}$ & $\begin{array}{l}1.4 \\
5\end{array}$ & $1.53 \mathrm{c}$ & $\begin{array}{l}0.8 \\
3\end{array}$ & $\begin{array}{l}- \\
0.2 \\
0\end{array}$ & $2.90 \mathrm{c}$ & $\begin{array}{l}1.4 \\
0\end{array}$ & $\begin{array}{l}1.1 \\
3\end{array}$ & $1.66 \mathrm{c}$ & $\begin{array}{l}1.0 \\
8\end{array}$ & $\begin{array}{l}0.2 \\
8\end{array}$ & $3.78 c$ & $\begin{array}{l}1.3 \\
5\end{array}$ & $\begin{array}{l}1.2 \\
9\end{array}$ & $3.93 c$ & $\begin{array}{l}1.6 \\
2\end{array}$ & $\begin{array}{l}1.8 \\
0\end{array}$ \\
\hline $\begin{array}{l}\text { A person } \\
\text { with } \\
\text { borderline } \\
\text { features }\end{array}$ & $4.83 d$ & $\begin{array}{l}1.4 \\
3\end{array}$ & $\begin{array}{l}2.1 \\
1\end{array}$ & $2.99 \mathrm{~b}$ & $\begin{array}{l}1.5 \\
4\end{array}$ & $\begin{array}{l}0.7 \\
8\end{array}$ & $4.38 \mathrm{~d}$ & $\begin{array}{l}1.3 \\
0\end{array}$ & $\begin{array}{l}2.3 \\
0\end{array}$ & $1.92 \mathrm{~d}$ & $\begin{array}{l}1.2 \\
9\end{array}$ & $\begin{array}{l}0.4 \\
4\end{array}$ & $.98 \mathrm{~d}$ & $\begin{array}{l}1.3 \\
1\end{array}$ & $\begin{array}{l}2.0 \\
1\end{array}$ & $45.41 d$ & $\begin{array}{l}1.3 \\
3\end{array}$ & $\begin{array}{l}3.3 \\
2\end{array}$ \\
\hline $\begin{array}{l}\text { A person } \\
\text { with } \\
\text { schizophr } \\
\text { enia }\end{array}$ & $5.29 \mathrm{e}$ & $\begin{array}{l}1.5 \\
1\end{array}$ & $\begin{array}{l}2.3 \\
0\end{array}$ & $3.68 \mathrm{~d}$ & $\begin{array}{l}1.7 \\
5\end{array}$ & $\begin{array}{l}1.0 \\
5\end{array}$ & $3.91 \mathrm{e}$ & $\begin{array}{l}1.4 \\
0\end{array}$ & $\begin{array}{l}1.8 \\
2\end{array}$ & $1.71 \mathrm{c}$ & $\begin{array}{l}1.1 \\
2\end{array}$ & $\begin{array}{l}0.3 \\
1\end{array}$ & $4.69 e$ & $\begin{array}{l}1.3 \\
8\end{array}$ & $\begin{array}{l}1.6 \\
8\end{array}$ & $5.69 e$ & $\begin{array}{l}1.3 \\
8\end{array}$ & $\begin{array}{l}3.4 \\
0\end{array}$ \\
\hline
\end{tabular}

Note. Higher mean scores indicate less positive ratings. Means in the same column that do not share subscripts differ at $p<$ .005 in the paired-sample $t$ test comparison. The $d$ statistic was calculated as $d=M_{c 1}-M_{c 2} / S_{p}\left(M_{c 1}=\right.$ mean of Condition 1 , $M_{\mathrm{c} 2}=$ mean of Condition 2, and $S_{\mathrm{p}}$ is the pooled standard deviation of the difference scores). Higher $d$ values indicate that the respondent rated greater incompatibility between self and target.

Regarding effectiveness ratings, all of the targets received ratings that were significantly different from each other ( $t$ statistic ranged from 4.63 to 40.09, all $p s<.001$ ). All three clinical targets obtained significantly lower effectiveness ratings than "a member of the public" and "yourself." The target "a person with schizophrenia" was rated as the least effective of all the targets.

All of the targets differed in terms of understandability ( $t$ statistic ranged from 1.24 to 22.14 , all $p s<$ .005), except for "a member of the public" and "a person with borderline features," which did not differ, $t(297)=1.24$, $n s$. The clinical target "a person with moderate depression" was rated as more understandable than both "a member of the public" and "yourself." The target "a person with schizophrenia" was rated as the least understandable of all the targets.

The targets differed significantly from each other on the safety ratings (tstatistic ranged from 2.92 to 39.98 , all ps <.005). Note that the clinical target "a person with moderate depression" obtained 
significantly higher safety ratings than did "a member of the public." The target "a person with borderline features" was rated as the least safe of all of the targets.

All of the targets differed from each other in terms of worthiness ( $t$ statistic ranged from 0.66 to 10.53, all $p$ s . 005), except for the "a person with moderate depression" and "a person with schizophrenia" targets, which did not differ, $t(299)=0.66, n s$. The target "a member of the public" was rated as the least worthy, followed by "a person with borderline features."

All of the targets obtained significantly different ratings in terms of desirability ( $t$ statistic ranged from 3.07 to 34.82 , all $p s<.005)$. The clinical targets were rated as less desirable to be with than "a member of the public" and "yourself." Overall, the target "a person with borderline features" was seen as the least desirable of all the targets.

All of the targets obtained significantly different ratings in terms of similarity ( $t$ statistic ranged from 3.56 to 58.97 , all $p s<.001$ ). The clinical targets were rated as less similar (to the respondent) than the target "a member of the public." The "a person with schizophrenia" target was seen as the least similar to me of all the targets.

$\underline{\text { J. Cohen's (1988) }}$ standardized mean difference statistic $(d)$ was calculated on self-versus-target ratings for each of the adjective pairs; these are shown in Table 1. Cohen's $d$ statistic expresses the magnitude of difference (or effect size) between self-ratings and ratings of other targets in standard deviation units. Higher $d$ values indicate a greater magnitude of difference and hence more dissimilarity or incompatibility between the respondent and the target. As shown in Table 1, the respondents generally viewed themselves more positively than all of the targets. The one exception, the target "a person with moderate depression" was rated as more understandable than "yourself" (this is represented as a negative $d$ value).

Overall, respondents viewed themselves as more comparable to the "a person with moderate depression" target than to "a member of the public" target in terms of effectiveness, understandability, safety, and worthiness but not in respect to desirability. The greatest discrepancy occurred in regard to the similarity-dissimilarity evaluations of the targets "a person with borderline features" and "a person with schizophrenia." Respondents viewed themselves as very incompatible to both of these targets.

Because respondents' ratings of targets varied extensively, and because group averages can obscure important features of data, the distributions of negative ratings were examined. Table 2 presents the percentages of psychologists giving extremely negative (6 or 7) ratings to the targets (not including the target "yourself"). Psychologists were much more likely to give extremely negative ratings to targets representing individuals with mental illness than to the target "a member of the public." For example, the target "a person with borderline features" was rated as highly undesirable by $42 \%$ of the psychologists, whereas $1 \%$ gave such a rating to the target "a member of the public." Likewise, the target "a person with schizophrenia" was rated as highly dissimilar to me by $69 \%$ of the psychologists, but only $4 \%$ gave this extreme rating to the target "a member of the public." 
Table 2

Percentages of Respondents Giving Extremely Negative Target Ratings

\begin{tabular}{lcrcrrr}
\hline \multicolumn{1}{c}{ Target } & \multicolumn{5}{c}{ Adjective } \\
\cline { 2 - 7 } & \% Ineffective & \% Incomprehensible & \% Dangerous & \% Unworthy & \% Undesirable & \% Dissimilar \\
\hline A member of the public & $<1$ & 2 & 1 & 2 & 1 & 4 \\
A person with moderate depression & 9 & $<1$ & 1 & $<1$ & 1 & 42 \\
A person with borderline features & 39 & 8 & 22 & 12 & 60 \\
A person with schizophrenia & 60 & 20 & 12 & 34 \\
\hline
\end{tabular}

Note. "Extremely negative target ratings" refers to ratings of 6 or 7 on a scale from 1 (most positive) to 7 (most negative).

Table 2 Percentages of Respondents Giving Extremely Negative Target Ratings

\begin{tabular}{|c|c|c|c|c|c|c|}
\hline & & & Adjective & & & \\
\hline Target & $\%$ Ineffective & $\%$ Incomprehensible & $\begin{array}{c}\% \\
\text { Dangerous }\end{array}$ & \% Unworthy & $\begin{array}{c}\% \\
\text { Undesirable }\end{array}$ & $\begin{array}{c}\% \\
\text { Dissimilar }\end{array}$ \\
\hline A member of the public & $<1$ & 2 & 1 & 2 & 1 & 4 \\
\hline A person with moderate depression & 9 & $\begin{array}{l}< \\
1\end{array}$ & 1 & $\begin{array}{l}< \\
1\end{array}$ & 8 & 24 \\
\hline A person with borderline features & 39 & 8 & 22 & 1 & 42 & 60 \\
\hline A person with schizophrenia & 60 & 20 & 12 & 1 & 34 & 69 \\
\hline
\end{tabular}

Note. "Extremely negative target ratings" refers to ratings of 6 or 7 on a scale from 1 (most positive) to 7 (most negative).

Finally, the psychologists' ratings of desirability ("to be with") and similarity ("to me") were of particular interest because they are the best indicators of disidentification. For this reason, regression analyses were conducted to predict the desirability of the target "a person with borderline features" and the similarity (to the rater) of the target "a person with schizophrenia." These targets were chosen for the analyses because they received the most negative ratings on the desirability and similarity adjective pairs. The borderline target was rated the least desirable and the schizophrenia target the most dissimilar. (Desirability and similarity were significantly correlated for both targets, $r=.45$ and .37, respectively.) The desirability and similarity ratings were predicted by using the other four adjectives (effectiveness, understandability, worthiness, and safety), which were entered simultaneously. The results are summarized in Table 3. The desirability of the target "a person with borderline features" and the similarity (to the rater) of the target "a person with schizophrenia" were both significantly associated with effectiveness and safety ratings but not understandability or worthiness ratings.

Table 3

Summary of Regression Analyses Predicting Similarity and Desirability Ratings

\begin{tabular}{lccccccc}
\hline & \multicolumn{3}{c}{ Similarity } & & \multicolumn{3}{c}{ Desirability } \\
\cline { 2 - 3 } \cline { 6 - 7 } \multicolumn{1}{c}{ Variable } & $B$ & $S E B$ & $\beta$ & & $B$ & SE B & $\beta$ \\
\hline Effectiveness & 0.17 & 0.05 & $.19^{*}$ & & 0.43 & 0.05 & $.47^{* *}$ \\
Understandability & 0.08 & 0.05 & .11 & & 0.03 & 0.04 & .03 \\
Worthiness & 0.07 & 0.07 & .05 & & 0.00 & 0.05 & .00 \\
Safety & 0.19 & 0.06 & $.19^{*}$ & & 0.21 & 0.05 & $.21^{* *}$ \\
\hline
\end{tabular}

Note. $R^{2}=.12$ for Similarity and .34 for Desirability $(p s<.001)$. The Similarity ratings concern the target "a person with schizophrenia." The Desirability ratings concern the target "a person with borderline features." $p<.01 .{ }^{* *} p<.001$. 
Table 3 Summary of Regression Analyses Predicting Similarity and Desirability Ratings

\begin{tabular}{|l|l|l|l|l|l|}
\hline \multicolumn{1}{|c|}{ Variable } & & Similarity & & & \\
\hline Effectiveness & $B$ & SE B & & \\
\hline Understandability & 0.17 & 0.05 & $.19^{*}$ & .11 & 0.43 \\
\hline Worthiness & 0.08 & 0.05 & 0.03 & 0.05 \\
\hline Safety & 0.07 & 0.07 & .05 & 0.00 \\
\hline
\end{tabular}

Note. $R^{2}=.12$ for Similarity and .34 for Desirability ( $p s<.001$ ). The Similarity ratings concern the target "a person with schizophrenia." The Desirability ratings concern the target "a person with borderline features."

${ }^{*} p<.01 .{ }^{* *} p<$

\section{Implications for Practice}

The findings suggest that persons with schizophrenia are viewed by clinical psychologists as considerably more ineffective and incomprehensible than individuals with other types of mental illness, whereas persons with borderline features are perceived as the most dangerous. Psychologists differentiate these individuals based on other characteristics as well, viewing persons with borderline features as undesirable and those with schizophrenia as the most dissimilar to the psychologists themselves. The study's respondents were demographically similar to respondents of prior surveys of psychologists (cf. Hershey, Kopplin, \& Cornell, 1991; Prochaska \& Norcross, 1983). When one considers that the respondents may have attempted to appear relatively unbiased and egalitarian and, similarly, that those who hold primarily favorable attitudes may have been most likely to respond to the survey, these results may reflect unrealistically more favorable attitudes than actually exist. Likewise, negative attitudes tend to be associated with stress and burnout, both of which are more common in public social service agencies and correctional facilities (Barnes, 1999). Psychologists from these types of settings were underrepresented in the survey. Finally, negative attitudes are most often exhibited by professionals who work with individuals displaying severe or chronic conditions (Minkoff, 1987; Mirabi et al., 1985). Such individuals were relatively uncommon in this study. On the basis of these factors, the results may underestimate the extent to which negative attitudes are present in the profession.

The results also suggest that disidentification is a dynamic that operates between psychologists and their clients. It could be claimed that the desire to distinguish oneself from individuals with mental illness is understandable to some extent. Powerful affective processes to maintain and enhance positive self-esteem operate universally (Dunning, Leuenberger, \& Sherman, 1995). Additionally, psychologists may be motivated to maintain perceptions of themselves consistent with their social identity as mental health professionals and with associated high levels of effectiveness, desirability, and safety (Hogg \& Abrams, 1988). Whether such motivations are acceptable or not is open to discussion. A disconcerting alternative explanation for disidentification is that it reflects a desire to distance oneself emotionally and intellectually from persons with mental illness.

It cannot be ignored that very negative responses were reported by a portion of psychologists for all clinical targets. For example, nearly half of the psychologists in the study view persons with borderline features as very undesirable and nearly three quarters consider persons with schizophrenia as very dissimilar to themselves. These indicators highlight the importance of tackling negative attitudes at an individual level as well as on a profession-wide basis. 
The extent to which psychologists judge that a person with severe mental illness is desirable to be with or similar to me appears to be related to their perceptions of the individual's safety and effectiveness. It is therefore particularly important that psychologists establish the origin and accuracy of these judgments. That is, psychologists must avoid falling prey to the type of cognitive biases and stereotypical thinking that underlie and foster the public's mistrust of individuals with mental illness.

If, as this study suggests, psychologists view themselves as distinctly different from individuals with psychosis and perceive individuals with personality disorders as undesirable, then concerns need to be raised in regard to the impact that these distinctions have on the therapeutic process. It is likely that such perceptions inhibit the therapist's ability to display empathy and genuine concern for these clients. These perceptions may contribute to overly pessimistic views in regard to treatment outcome and may discourage the efforts of those trying to recover from mental illness (Packer, Prendergast, Wasylenki, Toner, \& Ali, 1994; Wahl, 1999). These perceptions may negatively influence treatment decisions, detract from the therapeutic relationship, and weaken the effectiveness of treatment (Coady, 1993; Dykeman \& Lafleur, 1996; Gallop, Lancee, \& Garfinkel, 1989; Hepworth, Rooney, \& Larsen, 1997). The willingness of clinicians to engage these individuals in treatment may also be affected (N. L. Cohen, 1990; Gallagher et al., 1991). Not only may biased professionals avoid treating certain client groups, but also individuals in need of services may avoid seeking help for fear of encountering negative reactions from mental health providers (Wahl, 1999). Finally, mental health professionals with negative attitudes may fail to challenge misperceptions of mental illness, may model inappropriate behavior, and may help perpetuate the public's stigmatization of those who suffer from psychiatric conditions (Dincin, 1993).

Although it is important to identify the type of evaluations that psychologists make of persons with mental illness, it is equally important to understand the origin of these evaluations. One important source of attitudes is professional training. Training may inadvertently enhance negative attitudes by encouraging psychologists to draw extreme or overly rigid distinctions between themselves and those they serve, thereby legitimizing the process of disidentification. Overemphasis on the psychologist as expert can create a divide that obscures the commonality between therapist and client. This very point was recognized by one respondent to the survey who wrote the comment that the target with borderline features was "in the grand scheme of things more similar [to me] than different." Similarly, psychologists might reconsider whether mental illness and mental health are best understood categorically or within a continuum. Categorical distinctions tend to create an "us" versus "them" mentality that contributes to the disidentification process. Finally, although psychologists are trained to look for abnormality and dysfunction in their clients, a more holistic approach that also recognizes the client's strengths and internal resources is neither contradictory nor inconsistent.

Not only must training programs be reviewed and examined for their potential to instill bias, but also training and continuing education programs must be designed to specifically combat bias. For instance, training programs on best practices for specific disorders should cover the topics of stereotyping and the stigmatization of persons with mental illness (Keane, 1991). Discussions and lectures should engender positive attitudes by actively promoting beliefs in the ability of persons with mental illness to recover and assume successful and productive roles in society (Aubry, Tefft, \& Currie, 1995). Another tool to combat negative attitudes is the use of mental health consumers as trainers: This approach has 
shown promise in terms of positively impacting the attitudes of professionals (e.g., Cook, Jonikas, \& Razzano, 1995). It is important to note that the supervision of psychologists in training should explicitly address the recognition and modification of attitudes toward mental illness (cf. Dressler, Prusoff, Mark, \& Shapiro, 1975).

The attitudes of psychologists toward those they serve are motivated by their humanitarian and professional interests as well as by their training and experience. However, these same professionals are also influenced by sociocultural and psychological factors that can give rise to negative perceptions, distancing, and disidentification. It is vital that the attitudes and perceptions of psychologists remain a focus for further discussion and examination.

\section{References}

American Psychological Association. (1997). 1997 Directory of the American Psychological Association. Washington, DC: Author.

Atwood, N. (1982, March). Professional prejudice and the psychotic client.Social Work, 172-177.

Aubry, T., Tefft, B., \& Currie, R. F. (1995). Predicting intentions of community residents toward neighbors with psychiatric disabilities. Psychosocial Rehabilitation Journal, 18, 51-66.

Barnes, A. (1999). On seeing people through "rust-colored glasses": A study of practitioners' perceptions of clients. Journal of Applied Social Sciences, 23, 13-20.

Bhugra, D. (1989). Attitudes towards mental illness. Acta Psychiatrica Scandinavica, 80, 1-12.

Bureau of Labor Statistics, U.S. Department of Labor. (2004). Occupational outlook handbook (20042005 ed.). Retrieved May 25, 2004, from http://www.bls.gov/oco/ocos056.htm

Calicchia, J. P. (1981a). Attitudinal comparison of mental health and non-mental health professionals toward ex-mental patients. The Journal of Psychology, 108, 35-41.

Calicchia, J. P. (1981b). Differential perceptions of psychiatrists, psychologists, and social workers toward the ex-mental patient. Journal of Community Psychology, 9, 361-366.

Cavior, N., \& Glogower, F. (1973). Effects of physical attractiveness of therapist and client on number of psychotherapy sessions. Proceedings of the American Psychological Association, USA, 81, 10691070.

Coady, N. F. (1993). The worker-client relationship revisited. Families in Society, 74, 291-298.

Cohen, J. (1988). Statistical power analysis for the behavioral sciences(2nd ed.). New York: Academic Press.

Cohen, N. L. (1990). Stigma is in the eye of the beholder: A hospital outreach program for treating homeless mentally ill people. Bulletin of the Menninger Clinic, 54, 255-258.

Cook, J. A., Jonikas, J. A., \& Razzano, L. (1995). A randomized evaluation of consumer versus nonconsumer training of state mental health service providers. Community Mental Health Journal, 31, 229-238.

Corrigan, P. W. (2004). How stigma interferes with mental health care.American Psychologist, 59, 614625.

Corrigan, P. W., River, L. P., Lundin, R. K., Uphoff Wasowski, K., Campion, J., Mathisen, J., et al. (2000). Stigmatizing attributions about mental illness.Journal of Community Psychology, 28, 91-102. 
Crawford, I., Humfleet, G., Ribordy, S. C., Ho, F. C., \& Vickers, V. L. (1991). Stigmatization of AIDS patients by mental health professionals.Professional Psychology: Research and Practice, 22, 357-361.

Cumming, E., \& Cumming, J. (1957). Closed ranks: An experiment in mental health education. Cambridge, MA: Harvard University Press.

Dincin, J. (1993). Ending stigma and discrimination begins at home.Hospital and Community Psychiatry, 44, 309.

Dressler, D. M., Prusoff, B., Mark, H., \& Shapiro, D. (1975). Clinician attitudes toward the suicide attempter. The Journal of Nervous and Mental Disease, 160, 146-155.

Dunning, D., Leuenberger, A., \& Sherman, D. A. (1995). A new look at motivated inference: Are selfserving theories of success a product of motivational forces?Journal of Personality and Social Psychology, 69, 58-68.

Dykeman, C., \& Lafleur, N. K. (1996). Counselors' adjective correlates of working alliance. Psychological Reports, 78, 563-570.

Gallagher, A. G., Gernez, T., \& Baker, L. J. V. (1991). Beliefs of psychologists about schizophrenia and their role in its treatment. The Irish Journal of Psychology, 12, 393-405.

Gallop, R., Lancee, W. J., \& Garfinkel, P. (1989). How nursing staff respond to the label "borderline personality disorder."Hospital and Community Psychiatry, 40, 815-819.

Hepworth, D. H., Rooney, R. H., \& Larsen, J. (1997). Direct social work practice: Theory and skills (5th ed.). Pacific Grove, CA: Brooks \& Cole.

Hershey, J. M., Kopplin, D. A., \& Cornell, J. E. (1991). Doctors of psychology: Their career experiences and attitudes toward degree and training. Professional Psychology: Research and Practice, 22, 351-356.

Hogg, M. A., \& Abrams, D. (1988). Social identifications: A social psychology of intergroup relations and group processes. London: Routledge.

Jorm, A. F., Korten, A. E., Jacomb, P. A., Christensen, H., \& Henderson, S. (1999). Attitudes towards people with a mental disorder: A survey of the Australian public and health professionals. Australian and New Zealand Journal of Psychiatry, 33, 77-83.

Jorm, A. F., Korten, A. E., Jacomb, P. A., Rodgers, B., \& Pollitt, P. (1997). Beliefs about the helpfulness of interventions for mental disorders: A comparison of general practitioners, psychiatrists, and clinical psychologists. Australian and New Zealand Journal of Psychiatry, 31, 844-851.

Kahle, D. B., \& White, R. M. (1991). Attitudes toward alcoholism among psychologists and marriage, family, and child counselors. Journal of Studies on Alcohol, 52, 321-324.

Keane, M. (1991). Acceptance vs. rejection: Nursing students' attitudes about mental illness. Perspectives in Psychiatric Care, 27, 13-18.

Lerner, M. J. (1980). The belief in a just world: A fundamental delusion. New York: Plenum.

Lerner, M. J., \& Simmons, C. H. (1966). Observer's reaction to the "innocent victim": Compassion or rejection?Journal of Personality and Social Psychology, 4, 203-210.

Levey, S., \& Howells, K. (1994). Accounting for the fear of schizophrenia.Journal of Community and Applied Social Psychology, 4, 313-328.

Levey, S., \& Howells, K. (1995). Dangerousness, unpredictability, and the fear of people with schizophrenia. The Journal of Forensic Psychiatry, 6, 19-39. 
Mahatane, J., \& Johnston, M. (1989). Unrealistic optimism and attitudes towards mental health. British Journal of Clinical Psychology, 28, 181-182.

Miles, A. (1981). The mentally ill in contemporary society. Oxford, England: Robertson.

Minkoff, K. (1987). Resistance of mental health professionals to working with the chronic mentally ill. New Directions for Mental Health Services, 33, 3-20.

Mirabi, M., Weinman, M. L., Magnetti, S. M., \& Keppler, K. N. (1985). Professional attitudes toward the chronic mentally ill. Hospital and Community Psychiatry, 36, 404-405.

Nunnally, J. (1961). Popular conceptions of mental health: Their development and change. New York: Holt, Rinehart, \& Winston.

Osgood, C. E., Suci, G. J., \& Tannenbaum, P. H. (1957). The measurement of meaning. Urbana, IL: University of Illinois Press.

Packer, S., Prendergast, P., Wasylenki, D., Toner, B., \& Ali, A. (1994). Psychiatric residents' attitudes toward patients with chronic mental illness. Hospital and Community Psychiatry, 45, 1117-1121.

Potamianos, G., Winter, D., Duffy, S. W., Gorman, D. M., \& Peters, T. J. (1985). The perception of problem drinkers by general hospital staff, general practitioners and alcoholic patients. Alcohol, 2, 563-566.

Prochaska, J. O., \& Norcross, J. C. (1983). Contemporary psychotherapists: A national survey of characteristics, practices, orientations, and attitudes. Psychotherapy: Theory, Research, and Practice, 20, 161-173.

Ramon, S. (1978). The meaning attached: Attitudes towards the mentally ill. Mental Health and Society, 5, 164-182.

Roskin, G., Carsen, M. L., Rabiner, C. J., \& Marell, S. K. (1988). Attitudes toward patients among different mental health professional groups.Comprehensive Psychiatry, 29, 188-194.

Sharf, R. S., \& Bishop, J. B. (1979). Counselors' feelings toward clients as related to intake judgments and outcome variables. Journal of Counseling Psychology, 26, 267-269.

Skinner, L. J., Berry, K. K., Griffith, S. E., \& Byers, B. (1995). Generalizability and specificity of the stigma associated with the mental illness label: A reconsideration twenty-five years later. Journal of Community Psychology, 23, 3-17.

St. Lawrence, J. S., Kelly, J. A., Owen, A. D., Hogan, I. G., \& Wilson, R. A. (1990). Psychologists' attitudes towards AIDS. Psychology and Health, 4, 357-365.

Tajfel, H., \& Turner, J. C. (1986). The social identity theory of inter-group behavior. In S. Worchel \& L. W.Austin (Eds.), Psychology of intergroup relations. Chicago: Nelson-Hall.

Turner, J. C., Oakes, P. J., Haslam, S. A., \& McGarty, C. (1994). Self and collective: Cognition and social context. Personality and Social Psychology Bulletin, 20, 454-463.

Wahl, O. F. (1999). Mental health consumers' experience of stigma.Schizophrenia Bulletin, 25, 467478.

Wills, T. A. (1978). Perceptions of clients by professional helpers.Psychological Bulletin, 85, 968-1000.

Zolik, E. S., \& Boyd, R. J. (1972). Attitudes toward patients and service delivery. Proceedings of the Annual Convention of the American Psychological Association, 7, 797-798.

Submitted: September 30, 2005 Revised: May 11, 2006 Accepted: May 18, 2006 
This publication is protected by US and international copyright laws and its content may not be copied without the copyright holders express written permission except for the print or download capabilities of the retrieval software used for access. This content is intended solely for the use of the individual user.

Source: Professional Psychology: Research and Practice. Vol. 38. (2), Apr, 2007 pp. 214-219)

Accession Number: 2007-04835-015

Digital Object Identifier: 10.1037/0735-7028.38.2.214 